\title{
Методичний підхід до вибору раціонального варіанту підтримання працездатності зенітної ракетної системи в умовах морального старіння третього роду
}

\author{
Вадим Лук'янчук А; Іван Ніколаєв В; Володимир Ткачов ${ }^{\text {; }}$ \\ Павло Опенько ${ }^{\mathrm{i}}$; Павло Дранник ${ }^{\mathrm{E}}$
}

Received: May 1, 2020 | Revised: June 2, 2020 | Accepted: June 30, 2020

DOI: $10.33445 /$ sds.2020.10.3.1

\begin{abstract}
Анотація
Результати досліджень, що опубліковано в статті, будуть корисні для фахівців логістичного забезпечення, які займаються питаннями організації експлуатації та відновлення озброєння та військової техніки. У статті розглядається методичний підхід щодо вирішення питання забезпечення вибору раціонального варіанту підтримання працездатності зенітної ракетної системи з урахуванням впливу морального старіння третього роду. Проаналізовані існуючі у науково-технічній літературі публікації, присвячені питанням прогнозування показників довговічності озброєння та військової техніки на основі логіко-ймовірнісних моделей, які враховують як зміну властивостей складових частин зенітних ракетних систем, так i можливості системи логістичного забезпечення щодо ії відновлення, встановлено, що питання завдання вибору раціонального варіанту підтримання технічного стану зенітних ракетних систем з урахуванням наведених факторів в них не розглядалося, що дозволило визначити невирішене наукове завдання, що полягає в подальшому розвитку науковометодичного апарату вибору раціонального варіанту підтримання технічного стану зенітних ракетних систем з урахуванням зміни властивостей елементів обладнання і можливостей системи логістичного забезпечення з відновлення ії технічного ресурсу.

Описана математична модель вибору раціонального варіанту підтримання технічного стану зенітної ракетної системи з урахуванням зміни властивостей елементів обладнання і можливостей системи відновлення їі технічного ресурсу. Показано, що вибір того або іншого варіанту повинний здійснюватися на основі оцінювання техніко-економічної ефективності компенсації деградації ресурсної відмовостійкості. Наведено, що для компенсації деградації ресурсної відмовостійкості зенітної ракетної системи можуть застосовуватися методи модернізації радіоелектронного обладнання і методи підвищення забезпеченості експлуатаційних процесів. На основі математичного апарату дерев граничного стану отримані аналітичні вирази для розрахунку оцінок показників техніко-економічної ефективності застосування різних методів компенсації ресурсної відмовостійкості зенітної ракетної системи. Запропонований підхід до обгрунтування вибору найбільш раціонального варіанта підтримання працездатності зенітної ракетної системи з точки зору максимуму техніко-економічної ефективності на основі використання результатів ранжирування оцінок показників техніко-економічної ефективності.
\end{abstract}

\footnotetext{
А Харківський національний університет Повітряних Сил імені Івана Кожедуба, д.т.н., С.н.с., начальник науково-дослідного відділу наукового центру, м. Харків, Україна, e-mail: super.vadim1973@ukr.net, ORCID: 0000-0001-5695-7723

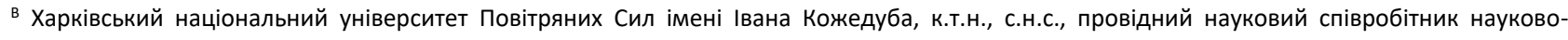
дослідного відділу наукового центру, м. Харків, Україна, e-mail: nikolaev49@ukr.net, ORCID: 0000-0002-1250-9918

' Національний університет оборони України імені Івана Черняховського, к. військ. н., провідний науковий співробітник науково-дослідного відділу інституту авіації та протиповітряної оборони, м. Київ, Україна, e-mail: vsk@vsk.com.ua, ORCID: 0000-0001-8957-2723

D Національний університет оборони України імені Івана Черняховського, м. Київ, Україна, к.т.н., начальник науково-дослідного відділу інституту авіації та протиповітряної оборони, e-mail: pavel.openko@ukr.net, ORCID: 0000-0001-7777-5101

Е Національний університет оборони України імені Івана Черняховського, к. військ. н., с.н.с., доцент кафедри зенітних ракетних військ інституту авіації та протиповітряної оборони, м. Київ, Україна, e-mail: pavchyc@ukr.net, ORCID: 0000-0002-6073-2962
} 
Ключові слова: зенітне ракетне озброєння, працездатний стан, моральне старіння, ресурсна відмовостійкість, метод компенсації, техніко-економічна ефективність.

\section{Постановка проблеми}

Сучасні зенітні ракетні системи (ЗРС) належать до найбільш складних і дорогих виробів озброєння [1]. Виходячи з цього більшість країн світу для вирішення завдань протиповітряної оборони (ППО) намагається використовувати ресурсний потенціал існуючого парку ЗРС до досягнення ними граничних меж ресурсних показників, до яких можлива їх безпечна експлуатація. Основними шляхами забезпечення справності та безпечності експлуатації ЗРС $€$ виконання ремонтів, продовження призначених термінів служби (ресурсів), експлуатація за технічним станом, а також модернізація за критерієм "ефективність-вартість" [2, 5]. Реалізація цих заходів повинна враховувати фактор морального старіння [3] і спиратися на відповідний науково-методичний апарат прогнозування динаміки зміни технічного стану та надійності ЗРС [4].

Моральне старіння ЗРС, які належать до класу складних технічних систем, може проявлятися в декількох формах [6, 7, 14]. Економічна форма морального старіння (або моральне старіння першого роду) має місце у ситуації, коли на ринку з'являються нові більш ефективніші ЗРС, внаслідок чого виробництво і використання застарілої техніки стає економічно недоцільним. Функціональна форма морального старіння (або моральне старіння другого роду) має місце у ситуації, коли бойові і функціональні можливості існуючих ЗРС не задовольняють вимогам боротьби з новими типами засобів повітряного нападу (ЗПН) противника. Внаслідок функціонального старіння ЗРС 3 часом переходять в категорію застарілого озброєння.

Крім зазначених форм морального старіння стосовно складних технічних систем запропоновано розглядати моральне старіння третього роду [9-12]. Ця форма морального старіння пов'язана, в основному, з деградацією можливостей відновлення працездатності ЗРС із-за вичерпання запасних частин, інструментів та приладів (ЗІП), неможливості поповнення ЗІП в результаті зняття комплектуючих виробів 3 виробництва, застосування застарілих технологій ремонту та відсутності фахівців 3 ремонту обладнання. Виходячи з викладеного, під моральним старінням третього роду розумітимемо деградацію (стійке зниження) можливостей відновлення здатності ЗРС вирішувати бойові завдання, що покладаються на неї, з необхідними характеристиками якості в умовах виникнення відмов апаратури i обладнання.

При моральному старіння третього роду зростає ймовірність переходу ЗРС в граничний стан, пов'язаний з неможливістю подальшої її експлуатації внаслідок появи неусувних відмов. Ця форма морального старіння, яка у науковотехнічній літературі получила назву “деградація ресурсної відмовостійкості" [9-12] у повної мірі розповсюджується на значну частину існуючого парку систем (комплексів) зенітного ракетного озброєння (ЗРО) Повітряних Сил Збройних Сил України. Аналіз свідчить, що існуюче системи (комплекси) ЗРО мають великі календарні терміни експлуатації, їх елементна база фізично і морально застаріла, комплекти зІП практично повністю використані, а їх ремонт ускладнений із-за відсутності спеціалізованих ремонтних органів, кваліфікованих фахівців та ремонтних комплектів ЗІП [5].

У ситуації, що склалася, актуальним $€$ пошук раціональних шляхів забезпечення справності та можливості подальшої безпечної експлуатації існуючого парку ЗРО. Одним 3 можливих шляхів вирішення цієї задачі $\epsilon$ розробка математичної моделі прогнозування меж граничних строків служби ЗРС як складної багатокомпонентної системи 3 блочномодульною побудовою складових частин (СЧ). 


\section{Аналіз останніх досліджень та публікацій}

Проблемі прогнозування морального старіння складних технічних систем різного призначення присвячено велика кількість публікацій [6-18].

В $[6,7]$ викладені основи апарата логікоймовірнісного числення, логіко-ймовірнісні моделі надійності структурно-складних систем та алгоритми перетворення функцій алгебри логіки у ймовірнісні функції.

Особливості обґрунтування методів управління розвитком розподілених інформаційних та вимірювальних систем у напрямі компенсації деградації ресурсної відмовостійкості на основі використання математичного апарату дерев граничного стану розглянуті в [8-15].

В [16] розглянутий методичний підхід до прогнозування показників довговічності об'єктів складних наземних комплексів, що відрізняється спільним (у рамках єдиної моделі) розглядом зміни властивостей елементів обладнання i можливостей системи відновлення технічного ресурсу (СВTP). Разом з тим, як показав проведений аналіз, у науково-технічній літературі відсутні публікації, присвячені питанням прогнозування показників довговічності ЗРС на основі логіко-ймовірнісних моделей, які враховують як зміну властивостей складових частин (СЧ) ЗРС, так і можливості СВТР.

Таким чином, проведений аналіз свідчить, що завдання вибору раціонального варіанту підтримання технічного стану ЗРС 3 урахуванням зміни властивостей елементів обладнання і можливостей системи відновлення ії технічного ресурсу $\epsilon$ невирішеним, а тема статті актуальною.

\section{Постановка завдання}

Вплив внутрішніх та зовнішніх факторів потребує постійної відповідності системи логістичного забезпечення збройних сил та інших військових формувань умовам, що склалися. Саме тому виникає необхідність наукового обґрунтування вибору найбільш раціонального варіанта підтримання працездатності ЗРС з точки зору максимуму техніко-економічної ефективності (TEE) на основі використання результатів ранжирування оцінок показників ТTЕ для подальшого використання в ході проведення оперативних та оперативно-тактичних розрахунків.
Отже, наукове завдання полягає в подальшому розвитку науково-методичного апарату вибору раціонального варіанту підтримання технічного стану ЗРС 3 урахуванням зміни властивостей елементів обладнання і можливостей системи відновлення її технічного ресурсу.

Метою статті $\epsilon$ викладення методичного підходу щодо обґрунтування раціонального способу компенсації деградації ресурсній відмовостійкості ЗРС з урахуванням значень показників TEE заходів, спрямованих на підтримання працездатності системи.

\section{Виклад основного матеріалу}

ЗРС з точки зору надійності $€$ складними відновлюваними технічними системами. Підтримання ЗРС у працездатному стані та відновлення ії технічного ресурсу здійснюється системою, до складу якої повинні входити спеціалізовані ремонтні підприємства, які повинні володіти відповідними технологіями ремонту, кваліфікованим персоналом та ремонтними комплектами ЗІП. Технічне обслуговування і поточний ремонт складових частин ЗРС здійснюється за допомогою спеціалізованих машини технічного обслуговування і ремонту (МРТО) та одиночних і групових комплектів ЗІП.

Продовження термінів експлуатації таких складних технічних систем як ЗРС тісно пов'язано з прогнозуванням довговічності, визначенням ресурсу і терміну служби. Визначенню підлягає залишковий ресурс, 
який визначає можливу тривалість безпечної експлуатації ЗРС до досягнення нею граничного значення. Продовження призначених показників терміну служби ЗРС повинне здійснюватися в межах прогнозованого залишкового терміну служби. При цьому прогнозування залишкового терміну служби ЗРС повинне здійснюватися з урахуванням зміни в часі надійності елементної бази і можливостей відновлення працездатності обладнання при відмовах. В умовах обмеженого обсягу статистичних даних рішення цієї задачі повинно забезпечуватися обґрунтованим вибором розмірності прогнозної моделі і використанням додаткової експертної інформації про надійність елементної бази.

Для прогнозування показників довговічності ЗРС в умовах дії процесу морального старіння третього роду необхідно розробити відповідну математичну модель ЗРС як відновлювальної системи 3 обмеженнями на можливість відновлення працездатності при відмовах ії елементів. У якості прийнятного класу моделей для моделювання морального старіння третього роду можуть бути використані логіко-ймовірнісні моделі дерев граничних станів (ДГС), які запропоновані і описані в [8-10]. В цих моделях для аналітичного запису умов працездатності ЗРС використовуються функції алгебри логіки та способи переходу від функцій алгебри логіки до імовірнісних функцій, які об'єктивно виражають надійність системи [6-10].

Згідно результатів робіт $[6,8,15]$, розробка математичної логіко-ймовірнісної моделі досягнення граничного стану ЗРС, яка має забезпечити прогнозування показників довговічності ЗРС в умовах деградації ресурсній відмовостійкості (з обмеженнями на можливість відновлення працездатності системи при відмовах ї̈ елементів), передбачає виконання певної сукупності робіт у декілька етапів, а саме:

збір загальних відомостей про ЗРС, до яких відносяться призначення, склад, основні тактико-технічні характеристики, принцип функціонування і відомості про складові частини;

аналіз технічної документації 3 метою встановлення характеру і конкретних умов роботи ЗРС, технічних параметрів, норм i критеріїв оцінки якості елементів, найбільш ймовірних відмов і ушкоджень. Аналізу підлягає нормативно-технічна, конструкторська і експлуатаційна документація. Дані про результати експлуатації для кожного 3 елементів складових частин ЗРС, а також джерела інформації заносяться в звідну таблицю;

обстеження технічного стану ЗРС, в ході якого проводиться візуальний контроль i контроль параметрів технічного стану СЧ ЗРС 3 використанням штатних засобів неруйнівного контролю;

збір статистичної і експертної інформації про технічний стан СЧ ЗРС 3 метою накопичення початкових даних для оцінювання технічного стану окремих елементів з використанням статистичних методів розрахунку параметрів надійності;

побудову за зібраними даними структурно-функціональної схеми і “дерева" досягнення граничного стану ЗРС у виді графічного відображення причиннонаслідкових зв'язків між переходом ЗРС в граничний стан і сукупністю початкових i проміжних подій, що відбивають зміну стану як самих елементів ЗРС, так і елементів СВТР;

вибір критеріїв і ознак ДГС СЧ ЗРС;

побудову на основі формалізації “дерева" досягнення граничного стану логікоімовірнісній моделі досягнення граничного стану ЗРС.

Для викладення суті методичного підходу до рішення задачі побудови математичної та логіко-ймовірнісній моделі досягнення граничного стану ЗРС будемо вважати, що до складу ЗРС входять $N$ різнотипних складових частин (СЧ), кожна з яких містить $l_{k}, k=\overline{1, N}$ функціональних пристроїв (ФП), а кожен ФП складається $3 \quad n_{k j}, j=\overline{1, m_{k}}$ елементів. У загальному випадку, до СЧ ЗРС відносяться РЛС виявлення цілій, РЛС супроводження і наведення ракет, пункти управлення, пускові 
та пуско-заряджальні установки, засоби електроживлення тощо. Склад і призначення ФП залежить від функціонального призначення СЧ ЗРС. Наприклад, до складу РЛС супроводження цілій і наведення ракет входять антенний, передавальний i приймальний пристрої, пристрої супроводження цілі за кутовими координатами, дальності та швидкості, пристрої захисту від перешкод, обчислювальний пристрій, індикаторні та інші пристрої.
Модель ДГС ЗРС має ієрархічну структуру i складається 3 наступних рівнів: “ЗРС складова частина (СЧ) - функціональний пристрій (ФП) СЧ - елемент" (мал.). Ця модель відображується у вигляді дерева граничного стану (ДГС) ЗРС і описує граничний стан і сукупністю початкових і проміжних подій, що відбивають зміну стану як елементів ЗРС, так і елементів СВТР.

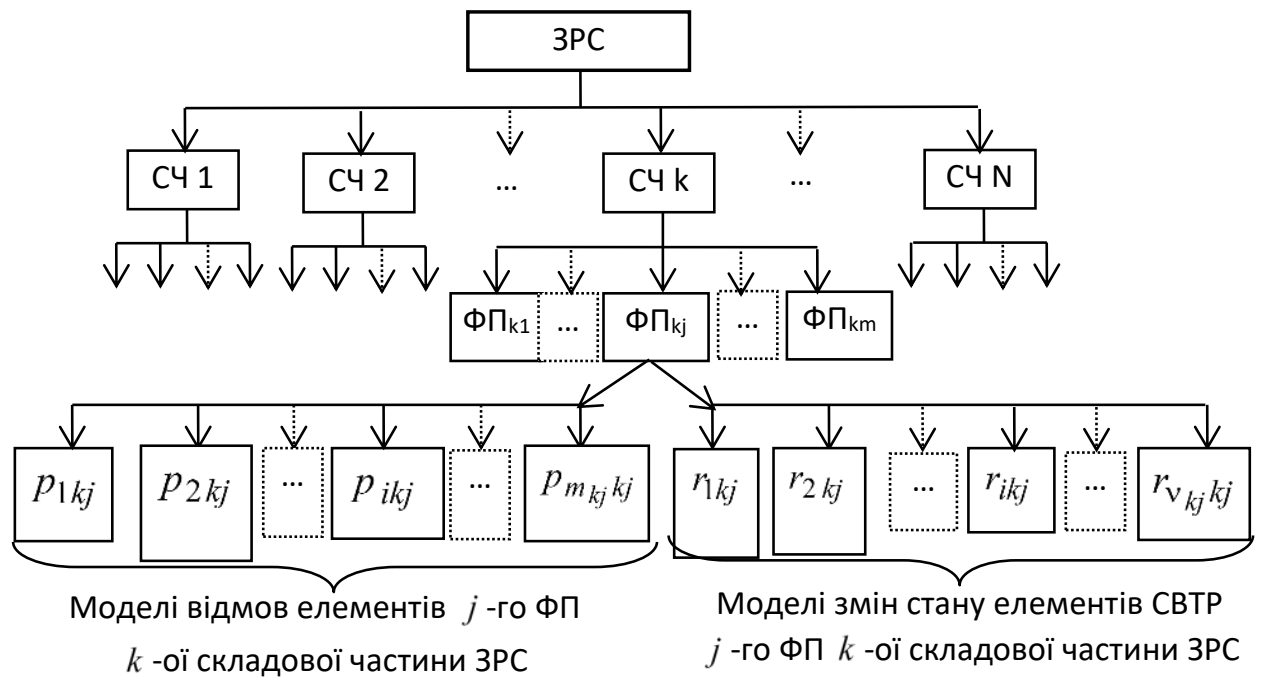

Мал. - Структурна схема моделі дерев недосягнення

граничного стану ЗРС

Умови досягнення граничного стану ЗРС можуть бути записані у вигляді булевої логічної функції шляхом формалізації “дерева" досягнення граничного стану [15]:

$$
Y_{3 P C}=Z_{C Y 1} \vee Z_{C Y 2} \vee \ldots \vee Z_{C Y N},
$$

де $Z_{C 4}$ - логічна функція досягнення граничного стану СЧ ЗРС.

Логічна функція $Y_{3 P C}$ за допомогою методів логіко-алгебраїчних перетворень може бути виражена через ймовірності недосягнення граничного стану складовими частинами і ЗРС у цілому. При цьому імовірнісна функція недосягнення граничного стану ЗРС бути мати наступний вигляд:

$$
P_{3 P C}(t)=p\left(P_{C Y 1}, P_{C \Psi 2}, \ldots, P_{C Y k}, \ldots, P_{C \Psi N}, t\right),
$$

де $P_{C ч k}(t)=\psi_{k}\left(p_{<l_{k}>}, r_{<v_{k}>}, t\right)$ - ймовірність недосягнення граничного стану $k$-ю СЧ ЗРС,

$p_{<m_{k}>}$ - вектор ймовірності безвідмовної роботи елементів $k$-ї складової частини.

Припустимо, що надійність функціонування СЧ (модулів) ЗРС характеризується вектором $p_{\left\langle l_{k}\right\rangle}=\left\langle p_{1 k}, p_{2 k, \ldots,} p_{i k}, \ldots, p_{l_{k} k}\right\rangle$, де $p_{i k}, i=\overline{1, J_{k}}$, $k=\overline{1, N},-$ значення ймовірності безвідмовної роботи елементів модулів ЗРС. Припустимо також, що заданий вектор $r_{\left\langle v_{k}\right\rangle}=\left\langle r_{1 k}, r_{2 k, \ldots}, r_{i k}, \ldots, r_{v_{k} k}\right\rangle$ ймовірності нормального функціонування елементів СВТР, задіяних при відновленні працездатності $k$-го модуля ЗРС, $k=\overline{1, N}$. Ці елементи $€$ зовнішніми по відношенню до структури ЗРС, але потрібні для дослідження запасу ії ресурсної відмовостійкості. 
Будемо розглядати чотири типи елементів СВТР ЗРС з ймовірністю: $r_{1 k}(t), r_{2 k}(t), r_{3 k}(t)$, $r_{4 k}(t), k=\overline{1, N}$, де елементи типу 1 характеризують поточну можливість невичерпання ЗІП модулів ЗРС; елементи типу 2 характеризують поточну можливість поповнення ЗІП модулів ЗРС; елементи типу 3 характеризують поточну міру наявності фахівців з ремонту модулів 3РС; елементи типу 4 характеризують поточну міру наявності доступних технологій ремонту модулів ЗРС.

Як показано в [10], зміна ймовірності недосягнення граничного стану ЗРС інтегрально визначається зміною технічного стану СЧ ЗРС і елементів СВТР. При цьому ймовірність недосягнення граничного стану ЗРС бути визначається, як $[8,9]$ :

$$
P_{3 P C}(t)=\prod_{k=1}^{N} \psi_{k}\left(p_{\left\langle l_{k}\right\rangle}, r_{\left\langle v_{k}\right\rangle}, t\right) .
$$

або

$$
P_{3 P C}(t)=\prod_{k=1}^{N}\left\{\begin{array}{l}
1-\left[1-p_{k}(t)\right] \times\left[1-r_{1 k}(t)\right] \times \\
\times\left[1-r_{2 k}(t)\right] \times\left[1-r_{3 i}(t) \times r_{4 k}(t)\right]
\end{array}\right\},
$$

де $p_{k}(t)$ - функція, що характеризує ймовірність безвідмовної роботи $k$-й СЧ ЗРС.

Значення $p_{k}(t)$ і $r_{1 i}(t)$ можуть бути розраховані на основі значень інтенсивності відмов $\lambda_{i}$ і середнього напрацювання на відмову $\bar{T}_{i}$ елементів СЧ ЗРС. Оцінки параметрів $\lambda_{i}$ і $\bar{T}_{i}$ можуть бути або узяті 3 довідників з надійності, отримані методом експертного оцінювання або розраховані за результатами моніторингу технічного стану. Значення ймовірності $r_{2 i}(t), r_{3}(t), r_{4 i}(t)$ для фіксованого тимчасового інтервалу $(0, t)$ пропонується оцінювати експертним методом за допомогою відповідних лінгвістичних шкал, що мають три градації оцінюваної ймовірності: $\{0 ; 0,5 ; 1\}$. У якості критеріїв граничного стану використовуються встановлені в стандартах і конструкторських документах ознаки стану ЗРС, при якому їі подальша експлуатація неможлива, недоцільна або небезпечна. У основу формування критеріїв граничного стану ЗРС доцільно покласти ознаки, що характеризують неможливість відновлення працездатного стану. У якості інших подій можуть, зокрема, розглядатися події, що полягають в зниженні можливостей системи відновлення технічного ресурсу (СВТР), а саме вичерпання і неможливість поповнення ЗІП, відсутність умов для проведення ремонту тощо.

Ймовірності подій, які $\epsilon$ компонентами імовірнісної функції досягнення граничного стану (ДГС), визначається виходячи з фізичної природи процесів, що призводять до настання кожного 3 них. Їх чисельні значення розраховуються на основі фізичних, фізикостатистичних або статистичних моделей, залежно від можливості отримання початкових даних i характеру процесів. Початковими даними для розрахунків $\epsilon$ параметри технічного стану, отримані в ході візуального і вимірювального контролю ЗРС. Критеріями граничного стану ЗРС $€$ встановлені в стандартах і конструкторських документах ознаки, при яких подальша експлуатація ЗРС неможлива, недоцільна або небезпечна. У основу формування критеріїв граничного стану ЗРС доцільно покласти ознаки, що характеризують неможливість відновлення працездатного стану.

Таким чином, можна бачити, що протидія прояву деградації ресурсної відмовостійкості ЗРС залежить від міри надійності обладнання ЗРС, фактичного запасу ЗІП, можливостей заповнення 3ІП, наявності фахівців з ремонту обладнання ЗРС і технологій ремонту. Для компенсації деградації ресурсній відмовостійкості ЗРС можуть бути застосовані: 1) методи модернізації обладнання і 2) методи підвищення забезпеченості експлуатаційних процесів ЗРС. Методи модернізації передбачають або заміну елементної бази ЗРС на сучаснішу, або застосування нових технічних рішень, або і те, і інше [10]. Друга група включає методи уточнення (коригування) обсягу i номенклатури та поліпшення механізмів поповнення ЗІП, збереження і вдосконалення ремонтних технологій та вдосконалення системи навчання фахівців з ремонту ЗРС. Вибір раціонального методу компенсації деградації ресурсній відмовостійкості ЗРС 3 
перерахованого вище переліку доцільно здійснювати на основі аналізу їх TEE [10].

Вважатимемо, що в результаті модернізації $j$-го ФП $k$-ї СЧ ЗРС його ймовірність безвідмовної роботи на інтервалі $\Delta t$ зростає на величину $\Delta p_{k j}$. При цьому витрати на модернізацію дорівнює $\Delta C_{k j}^{p}$, а приріст ВНГС ЗРС при цій модернізації складе $\Delta P^{(\text {мод })}$. Тоді показник TEE модернізації $j$-го ФП $k$-ї СЧ ЗРС можна оцінити як

$$
\omega_{\text {мод }}=\frac{\Delta P^{(\text {мод })}}{\Delta C_{k j}^{p}}=\frac{\left[P_{p_{1 k}}^{<1>}(t)-P_{p_{1 k}}^{<0>}(t)\right] \Delta p_{k j}}{\Delta C_{k j}^{p}},
$$

де $P_{p_{k}}^{<1>}(t)$ - значення ВНГС ЗРС, розраховане при значеннях ймовірності $p_{k}=1$, а $P_{p_{k}}^{<0>}(t)-$ відповідна оцінка ВНПС ЗРС при нульових значеннях ймовірності $p_{k}$.

Розглянемо особливості оцінювання показників TEE для окремих методів компенсації деградації ресурної відмостійкості ЗРС. Будемо вважати, що модернізація забезпеченості експлуатації для $i$-го модуля ЗРС збільшує ймовірність $r_{1 i}(t)$ невичерпання зІП $i$ -го модуля на інтервалі $\Delta t$ на величину $r_{1 i}$. При цьому витрати на модернізацію складають $\Delta C_{1 i}^{r}$, а ВНГС ЗРС зростає на величину $\Delta P^{\left(r_{1 i}\right)}$. Тоді оцінка показника ТЕE доцільності коригування обсягу і номенклатури ЗІП $i$-го модуля ЗРС може бути розрахована як [10]

$$
\omega_{r_{i i}}^{\text {мод }}=\frac{\Delta P^{\left(r_{1 i}\right)}}{\Delta C_{1 i}^{r}}=\frac{\left[P_{r_{i i}}^{<1>}(t)-P_{r_{i i}}^{<0>}(t)\right] \Delta r_{1 i}}{\Delta C_{1 i}^{r}}
$$

При цьому оцінка показника TEE доцільності коригування обсягу і номенклатури ЗІП для ЗРС в цілому може бути розрахована як [10]

$$
W_{3 P C\left(r_{1}\right)}^{\operatorname{Mod}}=\frac{\left.\sum_{j \in \Omega_{\{n\}}^{r}} \mid P_{r_{1 j}}^{<1>}(t)-P_{p_{1 j}}^{<0>}(t)\right\rfloor \Delta r_{1 j}}{\sum_{k \in \Omega_{\{n\}}^{r}} \Delta C_{1 k}^{r}}
$$

де $\Omega_{\{m\}}^{r}$ - підмножина індексів для елементів $r_{1}$
Аналогічним чином розраховуються оцінки TEE поліпшення механізмів поповнення ЗІП, вдосконалення системи навчання фахівців ремонту модулів ЗРС, збереження і вдосконалення ремонтних технологій.

3 викладеного виходить алгоритм реалізації пошуку найбільш ефективного методу компенсації деградації ресурсній відмовостійкості ЗРС.

1. На основі аналізу дерева граничних станів ЗРС визначається вид залежності (тобто ймовірність недосягнення граничного стану ЗРС від ймовірності безвідмовної роботи елементів обладнання ЗРС і ймовірність надійного функціонування елементів підсистеми відновлення технічного ресурсу ЗРС).

2. Оцінюються значення ймовірності безвідмовної роботи модулів $p_{1 k}$, а також значення $r_{1 k}(t)$ (невичерпання ЗІП ЗРС), $r_{2 k}(t)$ (поповнення 3ІП), $r_{3 k}(t)$ (наявності фахівців 3 ремонту С4 3РС), $r_{4 k}(t)$ (наявності доступних технологій ремонту СЧ ЗРС, де $k=\overline{1, N}$, на інтервалі $\Delta t$.

3. Оцінюються величини приростів ймовірності і відповідні витрати для кожного модуля по усіх даних методах модернізації.

4. Розраховуються оцінки показників TEE для окремих методів модернізації.

5. Ранжируються оцінки показників TEE.

6. Здійснюється вибір найбільш ефективного методу компенсації деградації ресурсній відмовостійкості ЗРС.

Таким чином, задачу формування методичного підходу щодо обґрунтування раціонального способу компенсації деградації ресурсній відмовостійкості ЗРС з урахуванням значень показників ТЕE заходів, спрямованих на підтримання працездатності системи можна вважати вирішеною.

Отримані результати рекомендовано використовувати для використання фахівцями логістичного забезпечення під час виконання заходів перспективного планування в органах військового управління. 


\section{Висновки}

Отже, за результатами досліджень встановлено, що моральне старіння третього роду ЗРС обумовлено моральним старінням елементної бази і деградацією ремонтних технологій, внаслідок чого зростає ймовірність переходу ЗРС в граничний стан, пов'язаний 3 неможливістю її подальшої експлуатації у зв'язку з появою неусувних відмов складових частин.

Описаний науково-методичний підхід до обґрунтування вибору найбільш раціонального варіанту підтримання працездатності ЗРС в умовах морального старіння третього роду базується на логікоймовірнісних моделях та спирається на математичний апарат дерев граничного стану. При цьому модель досягнення граничного стану ЗРС може бути представлена у вигляді логіко-ймовірнісної моделі причинно-наслідкових зв'язків між переходом ЗРС в граничний стан і сукупністю початкових і проміжних подій, що відбивають зміну стану як самих елементів ЗРС, так і елементів системи відновлення технічного ресурсу. Модель має ієрархічну структуру і відображується у вигляді дерева граничного стану ЗРС.

Рішення задачі компенсації деградації ресурсної відмовостійкості ЗРС здійснюється на основі результатів ранжирування оцінок показників TEE. Реалізація запропонованого підходу вимагає подальшого розвитку відповідних математичних моделей в умовах істотної невизначеності, джерелами якої $\epsilon$ недостатні обсяги фактографічної інформації про фактичний технічний стан парку ЗРС, що дозволяє визначити напрям подальших досліджень.

\section{Список використаних джерел}

1. Коровин А. Н. Ракетные комплексы ПВО: тенденции развития. URL: https://topwar.ru/ 2217-raketnye-kompleksy-pvo-tendenciirazvitiya.html

2. Гриб Д. А. Концептуальные подходы к развитию и поддержанию в боеготовом состоянии зенитного ракетного вооружения Воздушных Сил ВСУ на период до 2025 года/ Д. А. Гриб, Б. Н. Ланецкий, В. В. Лукьянчук, И. М. Николаев. - Збірник наукових праць. Х.: ХУПС. - 2010. - № 15. - С. 20-36.

3. Митчелл Р. Моральный износ и как с ним бороться [Електронний ресурс] /Митчелл Р. // Computer world Россия. - 2008. - №32. URL: $\quad$ https://www.osp.ru/cw/2008/32/ 5462756/

4. Ланецкий Б. Н. Комплексное оценивание показателей безотказности и остаточной долговечности сложных технических систем, эксплуатируемых по техническому состоянию. Основные положення. / Б. Н. Ланецкий, В. В. Лукьянчук, А. А. Артеменко // Системи обробки інформації, 2016, випуск 2 (139). - С. 40-43.

5. Карпенко Д. В. Стан та перспективи розвитку зенітного ракетного озброєння Повітряних
Сил Збройних Сил України. Наука і техніка Повітряних Сил Збройних Сил України. 2017. № 2(27). с. 75-78. URL: https://www. ukrmilitary.com/2017/05/state-amd-perspecti ves-of-development-of-anti-aircraft-missilearmament.html

6. Рябинин И. А. Логико-вероятностное исчисление как аппарат исследования надежности и безопасности структурносложных систем. Автоматика $u$ телемеханика. 2003. выпуск 7. С. 178-186.

7. Picardi C. Model synthesis for model-based fault analysis. / C. Picardi, L. Console, D. Th. Dupre // In Proceedings of the 15th International Workshop on Principles of Diagnosis. / Carcassonne - 2004.

8. Шестопалова О.Л. Прогнозирование моральной долговечности распределенных информационных систем с учетом прогрессирующих ограничений на возможности восстановления ресурса элементной базы. Современные проблемы науки и образования. 2013. № 6. URL: https://science-education.ru/ru/article/view? $\underline{\mathrm{id}=11078 .}$. 
9. Шестопалова О. Л., Муравьев А В. Прогнозирование срока службы информационной системы с учетом морального старения элементной базы технических средств. Транспортное дело России. 2014. №6. С. 186-189.

10. Шестопалова О. Л. Управление развитием информационных систем с учетом мониторинга морального старения. Современные наукоемкие технологии. 2017. № 6. C. 103-107. URL: http://www.toptechnologies.ru/ru/article/view?id=36707

11. Гузенко В.Л. Постановка задачи обеспечения технико-экономической эффективности эксплуатации распределе нной информационной системы /В.Л. Гузенко, А. В. Клепов, А. Н. Миронов., О. Л. Шестопалова. Современные проблемы науки и образования. 2014. №2. URL: https://science-education.ru/ru/article/view ?id=12361

12. Миронов А. Н. Индивидуально-групповое прогнозирование остаточного ресурса измерительных комплексов по экономическому критерию / А. Н. Миронов, А. Н. Новиков, А. В. Малахов // Наукоемкие технологии в космических исследованиях Земли. 2016. T. 8. № 4. С. 25-30. URL: http://www.h-es.ru/ru/citation-ru/2016.html

13. Миронов Е. А. Обоснование предпочтительного варианта построения и функционирования системы технической эксплуатации территориально-распределенной информационной системы по вектору

технико-экономических показателей / Е.А.Миронов, В.Л.Гузенко, А. В. Клёпов, О.Л. Шестопалова // Современные проблемы науки и образования. Издательский Дом "Академия Естествознания". 2014. № 3. URL: https://elibrary.ru/item.asp?id=22527871

14. Зеленцов В.А. Прогнозирование показателей долговечности стартовых комплексов на основе интегрированных структурных моделей предельного состояния / В. А. Зеленцов, А. Н. Миронов, В. Е. Прохорович // Двойные технологии. 2000. №1. C. 23-25. URL: http://www.sipria.ru/dt20 01.html

15. Миронов А.Н. Методика обоснования возможности и условий продления назначенных показателей срока службы антенных систем наземных станций измерительного комплекса космодрома / А. Н. Миронов, К. Ю. Цветков, А. А. Ковальский, В. Ю. Пальгунов // Труды МАИ. 2018. Выпуск № $99 . \quad$ URL: http://trudymai.ru/upload/iblock/c3e/ Mironov TSvetkov Kovalskiy Palgunov rus.p df?!

16. Бессонов П. Е., Пивоваров О. Г. Прогнозирование показателей долговечности объектов наземных комплексов с учетом неполноты информации о возможностях восстановлении работоспособности / Космос. 2011. № 2. С. 54-57. URL: http://www.infokosmo.ru/file/article/ 14380.pdf

\title{
Методический подход к выбору рационального варианта поддержание работоспособности зенитной ракетной системы в условиях морального старения третьего рода
}

\author{
Вадим Лукъянчук ${ }^{\text {A }}$, Иван Николаев ${ }^{\text {B }}$, Владимир Ткачев ${ }^{\text {, }}$ \\ Павел Опенько ${ }^{\mathrm{D}}$, Павел Дранник ${ }^{\mathrm{E}}$ \\ А Харьковский национальный университет Воздушных Сил имени Ивана Кожедуба, e-mail: super.vadim1973@ukr.net, \\ доктор технических наук, с.н.с, начальник научно-исследовательского отдела научного центра Воздушных Сил

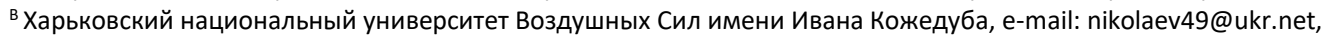 \\ к.т.н., с.н.с., ведущий научный сотрудник научно-исследовательского отдела научного центра Воздушных Сил \\ с Национальный университет обороны Украины имени Ивана Черняховского, e-mail: vsk@vsk.com.ua, к.в.н., профессор, \\ ведущий научный сотрудник научно-исследовательского отдела института авиации и противовоздушной обороны \\ D Национальный университет обороны Украины имени Ивана Черняховского, e-mail: pavel.openko@ukr.net, \\ к.т.н., начальник научно-исследовательского отдела института авиации и противовоздушной обороны \\ Е Национальный университет обороны Украины имени Ивана Черняховского, e-mail: pavchyc@ukr.net,
}


к.в.н., с.н.с., доцент кафедры зенитных ракетных войск института авиации и противовоздушной обороны

\title{
Аннотация
}

Результаты исследований, опубликовано в статье, будут полезны для специалистов логистического обеспечения, которые занимаются вопросами организации эксплуатации и восстановления вооружения и военной техники. В статье рассматривается методический подход к решению вопроса обеспечения выбора рационального варианта поддержания работоспособности зенитной ракетной системы с учетом влияния морального старения третьего рода. Проанализированы существующие в научнотехнической литературе публикации, посвященные вопросам прогнозирования показателей долговечности вооружения и военной техники на основе логиковероятностных моделей, учитывающих как изменение свойств составных частей зенитных ракетных систем, так и возможности системы логистического обеспечения по ее восстановлению, установлено, что вопросы задача выбора рационального варианта поддержания технического состояния зенитных ракетных систем с учетом приведенных факторов в них не рассматривалось, что позволило определить нерешенный научная задача, которая заключается в дальнейшем развитии научно-методического аппарата выбора рационального варианта поддержания технического состояния зенитных ракетных систем с учетом изменения свойств элементов оборудования и возможностей системы логистического обеспечения по восстановлению ее технического ресурса.

Описанная математическая модель выбора рационального варианта поддержания технического состояния зенитной ракетной системы с учетом изменения свойств элементов оборудования и возможностей системы восстановления ее технического ресурса. Показано, что выбор того или иного варианта должен осуществляться на основе оценки технико-экономической эффективности компенсации деградации ресурсной отказоустойчивости. Показано, что для компенсации деградации ресурсной отказоустойчивости зенитной ракетной системы могут применяться методы модернизации радиоэлектронного оборудования и методы повышения обеспеченности эксплуатационных процессов. На основе математического аппарата деревьев предельного состояния получены аналитические выражения для расчета оценок показателей технико-экономической эффективности применения различных методов компенсации ресурсной отказоустойчивости зенитной ракетной системы. Предложенный подход к обоснованию выбора наиболее рационального варианта поддержания работоспособности зенитной ракетной системы с точки зрения максимума технико-экономической эффективности на основе использования результатов ранжирования оценок показателей технико-экономической эффективности.

Ключевые слова: зенитное ракетное вооружение, работоспособное состояние, моральное старение, ресурсная отказоустойчивость, метод компенсации, техникоэкономическая эффективность.

\section{Methodical approach to the choice of a rational option maintainability of an anti-aircraft missile system in the conditions of moral aging of the third general}

\author{
Vadym Lukyanchuk ${ }^{\text {, }}$, Ivan Nikolaev ${ }^{\mathrm{B}}$, Volodymyr Tkachev ${ }^{\mathrm{C}}$, \\ Pavlo Open'ko ${ }^{D}$, Pavlo Drannyk ${ }^{\mathrm{E}}$ \\ A Ivan Kozhedub Kharkiv National Air Force University, e-mail: super.vadim1973@ukr.net, \\ Doctor of Technical Sciences, Senior Reseacher, Chief of Scientific-research Department of scientific center of Air Force \\ B Ivan Kozhedub Kharkiv National Air Force University, e-mail: nikolaev49@ukr.net, \\ Ph.D. in Technical Science, Senior Reseacher, Leading Reseacher of the Scientific-research Department of scientific center of Air Force \\ c The National Defense University of Ukraine named after Ivan Cherniakhovskyi, e-mail: vsk@vsk.com.ua, \\ Ph.D.in Military Sciences, Professor, Leading Researcher of the Scientific-research Department of the Aviation and Air Defence Institute
}




\footnotetext{
D The National Defense University of Ukraine named after Ivan Cherniakhovskyi, e-mail: pavel.openko@ukr.net, Ph.D.in Technical Science, Head of the Scientific-research Department of the Aviation and Air Defence Institute

EThe National Defense University of Ukraine named after Ivan Cherniakhovskyi, e-mail: pavchyc@ukr.net, Ph.D. in Military Sciences, Senior Researcher, Associate Professor, Department of Aircraft Missile Forces of the Aviation and Air Defence Institute
}

\begin{abstract}
The results of the research published in the article will be useful for logistic support specialists who are involved in the organization of the operation and renewal of weapons and military equipment. The article discusses the methodical approach to solving the question of ensuring the choice of a rational option for maintaining the efficiency of the anti-aircraft missile system, taking into account the impact of moral aging of the third kind. The publications in the scientific and technical literature on the issues of predicting the durability of weapons and military equipment based on logical-probabilistic models, which take into account both changes in the properties of components of anti-aircraft missile systems, as well as the possibility of its logistics support system, analyzed the task of choosing a rational option for maintaining the technical condition of anti-aircraft missile systems, taking into account the above factors, they were not considered, which allowed to determine the unsolved scientific problem, which consists in the further development of the scientific and methodological approach of choosing a rational variant of maintaining the technical condition of the anti-aircraft missile systems, taking into account the change of the properties of the elements of the equipment and the capabilities of the logistics system to restore its technical resource.

A mathematical model of choosing a rational option for maintaining the technical condition of an anti-aircraft missile system is described taking into account changes in the properties of equipment elements and the capabilities of a system for restoring its technical resource. It is shown that the choice of one or another variant of maintaining the operability of an antiaircraft missile system should be based on assessments of the technical and economic efficiency of compensating for the degradation of resource fail-safety. It is shown that to compensate for the degradation of resource fail-safety of the air defense system's operability, methods of modernizing electronic equipment and methods to increase the availability of operational processes can be used. Based on the mathematical apparatus of the trees of the limiting state, analytical expressions are obtained for calculating the estimates of the indicators of technical and economic efficiency of the application of various methods of compensating for resource fail-safety. An approach is proposed to justify the choice of the most rational option for maintaining the health of air defense systems by the criterion of maximum technical and economic efficiency based on the results of ranking estimates of technical and economic efficiency indicators.
\end{abstract}

Keywords: anti-aircraft missile weapons, operational state, moral aging, resource resistance, compensation method, technical and economic efficiency.

\title{
References
}

1. Korovin A. "Raketnyye kompleksy PVO: tendentsii razvitiya" [Missile defense systems: development trends], available at: https://topwar.ru/2217-raketnyekompleksy-pvo-tendencii-razvitiya.html

2. Grib D., Lanetskiy B., Luk'yanchuk V., Nikolaev I. (2010). Kontseptual'nyye podkhody k razvitiyu i podderzhaniyu $\mathrm{v}$ boyegotovom sostoyanii zenitnogo raketnogo vooruzheniya Vozdushnykh Sil VSU na period do 2025 goda" [Conceptual approaches to the development and combat readiness of antiaircraft missile weapons of the Air Force of the Armed Forces for the period until 2025]. Collection of scientific papers, KHUPS, No 15, pp. 20-36.

3. Mitchell R. (2008). "Moral'nyy iznos i kak s nim borot'sya" [Moral depreciation and how to deal with it]. Computer world Russia, No. 32, available at: https://www.osp.ru/cw/ 2008/32/5462756/. 
4. Lanetskiy B., Luk'yanchuk V., Artemenko A. (2016). "Kompleksnoye otsenivaniye pokazateley bezotkaznosti i ostatochnoy dolgovechnosti slozhnykh tekhnicheskikh sistem, ekspluatiruyemykh po tekhnicheskomu sostoyaniyu. Osnovnyye polozhennya" [Comprehensive assessment of reliability and residual durability of complex technical systems operated by technical condition. The main provisions], Information Processing Systems, issue 2 (139), pp. 40-43.

5. Karpenko D. (2017). "Stan ta perspektyvy rozvytku zenitnoho raketnoho ozbroyennya Povitryanykh Syl Zbroynykh Syl Ukrayiny" [State and prospects of development of air defense missiles of the Ukrainian Armed Forces]. Science and Technology of the Air Force of the Armed Forces of Ukraine, No.2 (27), pp.75-78, available at: https://www.ukrmilitary.com/2017/05/state -amd-perspectives-of-development-of-antiaircraft-missile-armament.html

6. Ryabinin I. (2003). "Logiko-veroyatnostnoye ischisleniye kak apparat issledovaniya nadezhnosti i bezo-pasnosti strukturnoslozhnykh sistem" [Logic-probabilistic calculus as an apparatus for studying the reliability and safety of structurally complex systems]. Automation and Telemechanics, Issue 7, pp. 178-186, available at: http://www.mathnet.ru/php/archive.phtml? wshow=paper\&jrnid=at $\&$ paperid=1918\&opti on_lang=rus

7. Picardi C. Model synthesis for model-based fault analysis. / C. Picardi, L. Console, D. Th. Dupre // In Proceedings of the 15th International Workshop on Principles of Diagnosis. / Carcassonne - 2004.

8. Shestopalova O. (2013) "Prognozirovaniye moral'noy dolgovechnosti raspredelennykh informatsionnykh sistem $s$ uchetom progressiruyushchikh ogranicheniy na vozmozhnosti vosstanovleniya resursa elementnoy bazy" [Prediction of the moral longevity of distributed information systems taking into account progressive restrictions on the possibility of restoring the resource of the element base], Modern problems of science and education, No.6, available at: https://science-education.ru/ru/article/ view?id=11078

9. Shestopalova O., Murav'ev A. (2014) "Prognozirovaniye sroka sluzhby informatsionnoy sistemy $s$ uchetom moral'nogo stareniya elementnoy bazy tekhnicheskikh sredstv" [Predicting the life of an information system, taking into account the moral aging of the hardware components base], Transport business of Russia, No. 6, pp. 186-189

10. Shestopalova O. (2017) "Upravleniye razvitiyem informatsionnykh sistem $\mathrm{s}$ uchetom monitoringa moral'nogo stareniya" [Management of the development of information systems taking into account monitoring of moral aging], Modern high technology, No. 6, pp. 103-107, available at: http://www.top-technologies.ru/ru/article/ view?id=36707

11. Mironov A., Novikov A., Malakhov A. (2016) "Individual'no-gruppovoye prognozirovaniye ostatochnogo resursa izmeritel'nykh kompleksov po ekonomicheskomu kriteriyu" [Individual-group forecasting of the residual life of measuring systems by the economic criterion], High technology in space exploration of the Earth, T. 8, No. 4, pp. 2530, available at: http://www.hes.ru/ru/citation-ru/2016.html

12. Mironov E., Guzenko V., Klopov A., Shestopalova O. (2014) "Obosnovaniye predpochtitel'nogo varianta postroyeniya $i$ funktsionirovaniya sistemy tekhnicheskoy ekspluatatsii territorial'no-raspredelennoy informatsionnoy sistemy po vektoru tekhniko-ekonomicheskikh pokazateley" [Justification of the preferred option for the construction and operation of the technical operation system of a geographically distributed information system in accordance with the vector of technical and economic indicators], Modern problems of science and education. Publishing House "Academy of Natural Sciences", No. 3, pp. 72, available at: https://elibrary.ru/item.asp?id=22527871

13. Guzenko V., Klepov A., Mironov E., Shestopalova O. (2014). "Postanovka zadachi 
obespecheniya tekhniko-ekonomicheskoy effektivnosti ekspluatatsii raspredelennoy informatsionnoy sistemy" [Statement of the problem of ensuring technical and economic efficiency of the operation of a distributed information system], Modern problems of science and education, 2014, No.2, available at: https://science-education.ru/ru/article/ view?id=12361

14. Zelentsov V., Mironov A., Prokhorovich V. (2000) "Prognozirovaniye pokazateley dolgovechnosti startovykh kompleksov na osnove integrirovannykh strukturnykh modeley predel'nogo sostoyaniya" [Prediction of durability indicators of launch complexes based on integrated structural models of the limiting state], Dual Technologies, No. 1. pp. $23-25$, available at: http://www.sipria.ru/dt20_01.htmlhttp://w ww.sipria.ru/dt20_01.html

15. Mironov A., Tsvetkov K., Koval'skiy A., Pal'gunov V. (2018) "Metodika obosnovaniya vozmozhnosti i usloviy prodleniya naznachennykh pokazateley sroka sluzhby antennykh sistem nazemnykh stantsiy izmeritel'nogo kompleksa kosmodroma" [Methodology for substantiating the possibility and conditions for extending the assigned indicators of the service life of the antenna systems of the ground stations of the cosmodrome measuring complex], Proceedings of the Moscow Aviation Institute, No. 99. http://trudymai.ru/upload/ iblock/c3e/Mironov_TSvetkov_Kovalskiy_Pal gunov_rus.pdf?!

16. Bessonov P., Pivovarov O. (2011) "Prognoziro-vaniye pokazateley dolgovechnosti ob"yektov nazemnykh kompleksov s uchetom nepolnoty informatsii o vozmozhnostyakh vosstanovlenii rabotosposobnosti" [Prediction of the durability indicators of objects of groundbased complexes, taking into account the incompleteness of information about the possibilities of restoration of working capacity], Cosmos, No. 2, pp. 54-57. available at: http://www.infokosmo.ru/file/ article/ 14380.pdf 